Article

\title{
An Analysis of the Effects of Climate Change Policy, Stakeholder Pressure, and Corporate Carbon Management on Carbon Efficiency on the Korean Petrochemical Industry
}

\author{
Soo-Hyun Lee and Su-Yol Lee * \\ College of Business Administration, Chonnam National University, Yongbong-ro 77, Buk-gu, Gwangju 61186, \\ Korea; lovingsh79@gmail.com \\ * Correspondence: leesuyol@jnu.ac.kr; Tel.: +82-10-8909-1446 or +82-62-530-1446
}

Received: 19 October 2018; Accepted: 24 November 2018; Published: 26 November 2018

check for updates

\begin{abstract}
Climate change is a challenging issue for government and society as well as in business circles; it has the potential to transform the competitive business environment entirely. This study analyzed the carbon efficiency of petrochemical companies subject to the Target Management System, a Korean carbon policy. The results of data envelopment analysis of 20 Korean petrochemical companies over three years yield some interesting findings. First, companies showed a wide range of carbon efficiency ranging from 0.05 (the least efficient) to 1.00 (the most efficient). Second, because this gap is so wide, the effect of the TMS carbon policy was not apparent. Third, pressure from media and financial investors facilitates carbon efficiency. Fourth, firms' efforts toward low-carbon product/technology development also improve carbon efficiency. This study provides some implications for managers and policy-makers who wish to foster firms' competitiveness and reduce greenhouse gas emissions at the same time.
\end{abstract}

Keywords: carbon efficiency; climate change policies; stakeholder pressure; corporate carbon management practices; data envelopment analysis; the Korean petrochemical industry

\section{Introduction}

Climate change has emerged as one of the most urgent and challenging issues for the government and society as well as for businesses. The Intergovernmental Panel on Climate Change [1] noted that the global average temperature had risen about $0.64{ }^{\circ} \mathrm{C}$ since the mid-21st century. Climate change would incur costs up to $15 \%$ of the global gross domestic product (GDP) and lead to the extinction of $20-30 \%$ of all existing species [2,3]. The Paris Agreement, settled in 2015 after a long-standing debate, has served as momentum for the transition to a low-carbon economy by setting out a global action plan to put the world on track by limiting global warming to well below $2{ }^{\circ} \mathrm{C}$.

Business circles have also realized that climate change has the potential to entirely transform the competitive business environment [4-6]. Particularly, newly designed carbon policies, such as the emission trading scheme (ETS), demand that companies play a vital role in mitigating continued global warming. Accounting for $1.7 \%$ of the world's total emissions, South Korea was the world's seventh biggest greenhouse gas (GHG) emitter as of 2010 [7]. The country announced its own voluntary medium-term mitigation goal to reduce GHG emissions by $37 \%$ of the business-as-usual level by 2030 . This national goal poses a challenge for businesses since more than half of Korea's total emissions are from the electricity and industry sectors [8]. Moreover, energy demand and GHG emissions have steeply increased by $31 \%$ and $25 \%$, respectively, for the last decade [7]. 
In general, South Korean companies have been against a national carbon policy and have argued that limiting emissions at a more stringent level than other countries such as China would increase manufacturing costs and weaken competitive advantage. However, it is reported that they have also shown different reactions to addressing climate change. While some companies are strongly opposed unfavorable climate regulations, others took a proactive stance by sensing an opportunity in the climate change issues [9]. Previous studies have attempted to gain a better understanding of the relationship between climate change policies and corporate responses by analyzing the potential gains or losses under a new carbon policy circumstance [10]. Academic research in this field, however, currently faces challenges at many levels.

First, few studies explore firms' responses to climate change policies from a managerial interpretation perspective. Firms' environmental strategies may differ even though they operate in the same regulatory context $[11,12]$. Managerial perceptions of carbon-related risks, pressure from external stakeholders such as customers and financial institutions, and the extent of resources and capabilities within an organization influence management decision-making, which in turn determines the range and level of corporate response to climate change [11,13]. However, the topic of how firms differ in interpreting the potential impacts of climate change on their business and deploying resources to respond to a new carbon policy, and consequently how such different reactions influence their competitiveness, remains unexplored. Second, South Korea has introduced a series of climate change policies since the early 2010s such as the target management system (TMS) and the emission trading scheme (ETS). However, little has been reported about how such carbon policies influence firms' carbon productivity. Third, corporate attitudes and management practices in addressing emerging environmental issues such as climate change have evolved. Very few studies examine changes in firms' relative carbon competitiveness regarding carbon policies from a dynamic perspective.

In light of this research gap, this study makes three contributions. First, we explore firms' competitiveness regarding climate change issues, particularly carbon policies. To our knowledge, this paper is the first study to employ carbon efficiency, measured as a ratio of outcomes per carbon emission unit, as a proxy for a firm's competitiveness regarding climate change. This study examines relative carbon efficiency and the change in its values among Korean petrochemical companies, one of the most energy-intensive and high-emission industries. Second, this study examines the effect of carbon policy on firms' competitiveness. We analyze changes in firms' carbon efficiency before and after the Korean TMS was put into effect. Third, this study investigates antecedents that might influence firms' carbon efficiency. We examine how stakeholder pressure and firms' carbon management practices influence their carbon efficiency. We employ data envelopment analysis (DEA) to analyze relative carbon efficiency. To examine the effect of a carbon policy (i.e., the Korean TMS) on carbon efficiency, a DEA window model was used. We also used a survey method to collect data relating to stakeholder pressure and firms' carbon management practices.

The findings collectively lay the groundwork for a better understanding of firms' carbon competitiveness (e.g., carbon efficiency) and its change by examining the interplay of government carbon policy, stakeholder pressure, and firms' carbon management practices. The study also provides some implications for managers as well as policy-makers who attempt to proactively address climate change issues from the perspective of industry and firm competitiveness.

\section{Theoretical and Policy Background}

\subsection{Korean Climate Change Policies}

This section provides a brief overview of South Korean government policies for climate change. South Korea adopted the National Strategy for Green Growth in 2009 aiming to promote eco-friendly growth and contribute to international efforts to fight global warming. Considering this strategy, the country announced its national goal to reduce greenhouse gas (GHG) emissions by $37 \%$ from business-as-usual levels by 2030. In 2010, the Framework Act on Low Carbon, Green Growth 
was enacted, which created the legislative framework for mid- and long-term emissions reduction targets, cap-and-trade, carbon labeling, carbon information disclosure, and other related policies. The Framework Act included a system of mandatory reporting of carbon emissions by all carbon- and energy-intensive industries and provided a basis for the enforcement of an emission trading scheme (ETS). As a precursor to the ETS, the TMS-a GHG management program with 490 entities and 1570 sites-was introduced and officially implemented in 2010 and 2012, respectively. As of 2011, the TMS covered almost $68 \%$ of the total GHG emissions in South Korea. The TMS imposed GHG reduction on large-scale facilities emitting a substantial quantity of GHGs and consuming a high level of energy, with energy conservation targets obliging them to meet their goals. South Korea officially launched its ETS in January 2015 amid strong resistance from the business circle and industries. The idea was to tighten regulations on companies' emissions step-by-step through a cap-and-trade system. Five hundred and twenty-five companies, among the country's biggest emitting entities, and consisting of private and government-owned organizations, have been subject to the ETS.

South Korea's carbon policies are still at the early stage and very few studies have reported on how these policies influence competitiveness as well as actual emission reduction. Such carbon policies are usually based on a voluntary mechanism and result-assessment, providing firms with autonomy in setting and achieving reduction targets. However, they have some limitations in that they are not able to fully consider the differences in each firm's circumstance [14,15]. For instance, some companies that had to curtail production due to the economic downturn are likely to be assessed as high performers regarding emission reductions. Data envelopment analysis (DEA) has been widely used in analyzing the effects of certain policies on individual firms' relative performance [16] and might apply for examining the effectiveness of a carbon policy [17].

\subsection{DEA in Environmental Studies}

DEA is recognized in the literature as a powerful method, more suitable for performance measurement activities than traditional, econometric methods such as regression analysis and simple ratio analysis. DEA is a mathematical method using linear programming techniques to convert inputs to outputs with the purpose of evaluating the performance of comparable organizations or products. In DEA, each DMU is free to choose any combination of inputs and outputs in order to maximize its relative efficiency. The relative efficiency or the efficiency score is the ratio of the total weighed output to the total weighed input. DEA uses linear programming to estimate relative efficiency. The relative efficiency, denoted by or, is the efficiency score allocated to a decision making unit as a result of the DEA. This relative efficiency is a non-negative value calculated based on linear relations between the inputs and outputs of the DMUs under analysis. In order words, it determines how efficient a DMU is in producing a certain level of output, based on the amount of input it uses, compared to similar DMUs [18].

DEA has been applied in environmental studies, particularly eco-efficiency evaluation $[19,20]$. Eco-efficiency is understood as a management philosophy and approach coined by the World Business Council for Sustainable Development [21] that aims at minimizing ecological damage while maximizing outcomes of the firm via the lesser use of energy, material, and water, more recycling, and elimination of hazardous emissions or by-products. The approach has spread widely, being used as a performance indicator in several industries to represent the ratio between the economic value and environmental impact [22-25].

The literature on eco-efficiency has two streams. First, previous studies focus on developing comprehensive efficiency measurement tools that better represent economic performance and environmental impact [16,26-28]. For example, Oggioni et al. [16] measure eco-efficiency by applying both a DEA and a directional distance function approach, which are particularly suitable for models where several production inputs and desirable and undesirable outputs are taken into account. Mahlberg et al. [26] analyze eco-efficiency change over time using the two-model variants of Korhonen and Luptacik [28], which could provide deeper insights concerning the driving forces for change 
in eco-efficiency. DEA can provide important policy implications about how to increase efficiency such as reductions in waste, labor, or capital. The second research stream focuses on determining the weights of inputs and outputs to construct a single eco-efficiency index $[19,20]$. For instance, Zadeh et al. [19] propose a new method that can keep in perfect control the dispersal of weights for appraising eco-efficiency. Kuosmanen and Kortelainen [20] consider DEA as a method for eco-efficiency measurement. While DEA does not require any a priori weights for various environmental pressures, normative judgments, and subjective valuations of weights can easily be incorporated into the model framework.

By applying the concept of eco-efficiency to the climate change realm, we define carbon efficiency as a firm's capacity to generate more value while reducing resource use and global warming impact. This study measures carbon efficiency as the ratio of total revenues to the corresponding energy consumption and carbon emissions of a firm. Collectively, we utilize a single indicator for relative carbon efficiency, representing a firm's capacity compared to the best performer among the comparing group.

\subsection{Stakeholder Pressure and Carbon Management Practices}

A variety of stakeholders maintain relationships with firms and affect them as well. A firm's attitude and practices towards climate change may change significantly depending on the degree of stakeholder concerns $[10,29]$, which in turn leads to a difference in carbon efficiency performance. This study considers four groups of stakeholders with regards to climate change issues: regulatory agencies, customers, media, and financial investors [30].

First, regulatory agencies are the most influential stakeholders regarding environmental issues. For instance, Lee [31] reported that firms in the energy-intensive sectors in South Korea tend to have a more proactive stance than firms in other general manufacturing sectors when addressing global warming issues. This is because such energy-intensive companies are generally under intense pressure from the government, which imposes regulations and forces these companies to disclose their carbon emissions. Second, customers may play a pivotal role in urging firms to integrate the climate change issues into their managerial decision-making. The market component continues to increase in importance as customers are increasingly concerned about climate change [6]. Third, media is another source of environmental pressure. In many cases, consumers also rely on second-hand information, primarily through the media. Media attention to climate change is one of the three most compelling factors (reputation, media attention, and customer preferences) that corporate respondents consider in addressing climate change [32]. Fourth, financial investors have emerged as a substantive source of pressure for firms in response to climate change. For instance, the Carbon Disclosure Project (CDP), a consortium of over 300 institutional investors with $\$ 41$ trillion in assets as of 2013, requested the world's top 500 firms annually to provide detailed information on their GHG emissions, risks, opportunities, and management strategies [30].

In addressing climate change and reducing GHG emissions, firms have a diverse range of management practices as strategic options, which are understood as carbon management practices. Based on the relevant literature [11,30,33-35], this study focuses on four types of activities: low-carbon product development, process efficiency improvement, energy source substitute, and organizational engagement. First, firms need to engage in "low-carbon product development", because the carbon footprint, representing the sum of a product's direct and indirect emissions in a firm's entire value chain, has gained importance. This practice includes developing energy-efficient products via incremental changes in existing technology and products as well as carbon-free technologies through radical innovations. Second, firms have typically focused on efforts to reduce emissions in production processes. "Process efficiency improvement" includes a diverse range of activities conducted on a manufacturing site to improve efficiency including plant retrofit, overhauling the entire production process, energy system optimization, and energy recovery from waste materials as well as the state-of-the-art new process technologies. Third, "energy source substitution" emerges as a potential 
option when firms need to reduce indirect GHG emissions generated from the use of electricity. By substituting existing energy sources with less carbon-generating fuels, such as liquid natural gas or renewable energy sources, companies can lower the levels of their carbon inventory. Last, firms need to engage employees and increase their awareness of emission reduction across the entire organization. In doing so, companies usually provide employees with training and education regarding climate change issues. They also redesign their performance assessment system by integrating emission reduction performance. For instance, BP has adopted an internal ETS that assigns emission targets to its several plants or departments and allows them to trade their emission credits when necessary to meet internal emission reduction targets.

\section{Research Methodology}

\subsection{Data Envelopment Analysis (DEA)}

We employ DEA to analyze the carbon efficiency of the Target Management System (TMS)-designated companies. Charnes et al. [36] proposed DEA to assess the relative efficiency of a set of homogeneous DMUs with multiple inputs and outputs. We selected the Korean petrochemical industry for two reasons. First, it is essential when using DEA to secure homogeneity between DMUs, so the literature recommends selecting companies in the same industry [17]. Second, the petrochemical industry, as one of the largest GHG emitting industries including steel and power, has been a target for Korean carbon policies [33]. Since the TMS came into effect in 2012, the largest number of TMS-designated firms has been in this industry. The official website of the TMS (http:/ / www.greencompany.or.kr) provides a list of companies subject to the TMS. Collectively, the petrochemical industry provides a sufficient number of companies to be compared for relative carbon efficiency using DEA. A total of 20 companies subject to the TMS in the petrochemical industry were selected as DMUs for our analysis. To examine the effect of the TMS policy on carbon efficiency, we conducted DEA over a three-year time span; DEA for 2011 as the 'before TMS' case; DEA for 2012 as the 'during TMS' case, and DEA for 2013 as the 'after TMS' case.

DEA has a variety of analytical approaches, and the final efficiency value as well as the weight between assumptions and variables for measurement may vary [37]. This study used the input-oriented CCR (CCR-I) model that has been most widely used in DEA. The CCR-I model aims to reduce the input amounts by as much as possible while maintaining at least the present output levels. The TMS 206-policy facilitates participating companies in reducing their GHG emissions and energy consumption while maintaining their economic outputs (e.g., sales). This is very similar to the improvement direction for eliminating inefficiency in the CCR-I model. The literature on eco-efficiency usually uses resource consumption and pollutant emissions as the efficiency input variable $[38,39]$ and sales or turnover as the output variable [40]. Following these previous studies, we measured energy consumption and GHG emissions for input variables and sales as the output variable. Input and output data were compiled from the Greenhouse Gas Inventory and Research Center and NICE financial database, respectively.

To enhance the validity of the DEA outcomes, the literature recommends that the number of DMUs should be three times larger than the total number of input and output variables [41-43]. This study complies with such validity criteria.

Table 1 presents the descriptive statistics of DMUs for carbon efficiency. The large degree of standard deviation is mainly because of the great differences in firm size. 
Table 1. Statistics of input and output variables for carbon efficiency DEA.

\begin{tabular}{|c|c|c|c|c|}
\hline \multirow{2}{*}{ Year } & \multirow{2}{*}{ Statistics } & \multicolumn{2}{|c|}{ Input Variables } & \multirow{2}{*}{$\begin{array}{c}\text { Output Variable } \\
\text { Sales }\left(\times 10^{3} \mathrm{KRW}\right) \\
\end{array}$} \\
\hline & & GHG Emission $\left(\times 10^{3} \mathrm{tCO}_{2}\right)$ & Energy Consumption $\left(\times 10^{3} \mathrm{TJ}\right)$ & \\
\hline \multirow[t]{4}{*}{2011} & Average & $1,094,757$ & 18,664 & $3,366,957,433$ \\
\hline & $\begin{array}{l}\text { Standard } \\
\text { Deviation }\end{array}$ & $1,502,129$ & 28,154 & $4,582,156,785$ \\
\hline & Max & $5,893,612$ & 112,502 & $19,809,874,000$ \\
\hline & Min & 35,749 & 654 & $33,190,322$ \\
\hline \multirow[t]{4}{*}{2012} & Average & $1,106,813$ & 19,285 & $3,303,602,680$ \\
\hline & $\begin{array}{l}\text { Standard } \\
\text { Deviation }\end{array}$ & $1,579,431$ & 30,236 & $4,715,472,832$ \\
\hline & $\operatorname{Max}$ & $6,392,472$ & 123,312 & $20,442,790,000$ \\
\hline & Min & 34,599 & 689 & $33,869,616$ \\
\hline \multirow[t]{4}{*}{2013} & Average & $1,132,417$ & 19,998 & $3,213,321,398$ \\
\hline & $\begin{array}{l}\text { Standard } \\
\text { Deviation }\end{array}$ & $1,696,178$ & 32,253 & $4,648,991,339$ \\
\hline & Max & $7,048,435$ & 135,357 & $20,255,935,000$ \\
\hline & Min & 31,903 & 636 & $38,611,304$ \\
\hline
\end{tabular}

\subsection{Survey: Stakeholder Pressure and Carbon Management Practices}

The present research utilizes a survey method to examine the effects of stakeholder pressure and firms' carbon management practices on carbon efficiency. The question items used in this study were developed based on the relevant literature (e.g., [11,30]). First, the perceived pressure of the four stakeholders (i.e., regulatory agencies, customers, media, and financial investors) was measured on a seven-point Likert-type scale. The four carbon management practices (i.e., low-carbon product development, process efficiency improvement, energy source substitution, and organizational involvement) were measured using the same Likert scale, reflecting the levels of the firm's adoption and implementation of these practices. Collectively, all question items were subjective measures (see Table A1). The research conducted a survey in 2011 to the 20 selected companies in the petrochemical industry subject to the TMS.

\section{Results and Discussion}

\subsection{Carbon Efficiency and Improvement Potential}

We analyzed the carbon efficiency of the 20 petrochemical companies subject to the TMS regarding GHG emissions, energy consumption, and sales for three years from 2011 to 2013 . Table 2 presents the carbon efficiency of the DMUs for each year, reference set (RS), and lambda ( $\lambda$ ) using a CCR-I model.

Table 2. Results of carbon efficiency using a CCR-I model.

\begin{tabular}{ccccccc}
\hline \multirow{2}{*}{ DMU } & \multicolumn{2}{c}{2011} & \multicolumn{2}{c}{2012} & \multicolumn{2}{c}{$\mathbf{2 0 1 3}$} \\
\cline { 2 - 6 } & Efficiency & RS( $\boldsymbol{\lambda})$ & Efficiency & RS $(\boldsymbol{\lambda})$ & Efficiency & RS $(\boldsymbol{\lambda})$ \\
\hline 1 & 0.119 & $11(1.652)$ & 0.08 & $11(1.162)$ & 0.064 & $11(0.750), 20(0.619)$ \\
2 & 0.351 & $11(0.750)$ & 0.304 & $11(0.712)$ & 0.216 & $11(0.553), 20(0.283)$ \\
3 & 0.277 & $11(2.566)$ & 0.242 & $11(2.349)$ & 0.181 & $11(1.020), 20(2.392)$ \\
4 & 0.832 & $11(1.575)$ & 0.773 & $11(1.612)$ & 0.583 & $11(1.188), 20(0.255)$ \\
5 & 0.674 & $11(1.652)$ & 0.439 & $11(1.162)$ & 0.331 & $11(0.629), 20(0.973)$ \\
6 & 0.154 & $11(0.978)$ & 0.144 & $11(1.001)$ & 0.123 & $11(0.820), 20(0.108)$ \\
7 & 0.046 & $11(0.016)$ & 0.044 & $11(0.016)$ & 0.043 & $11(0.005), 20(0.035)$ \\
8 & 0.459 & $11(0.099)$ & 0.472 & $11(0.113)$ & 0.485 & $11(0.109), 20(0.008)$ \\
9 & 0.094 & $11(0.181)$ & 0.087 & $11(0.195)$ & 0.056 & $11(0.147), 20(0.061)$ \\
10 & 0.323 & $11(0.290)$ & 0.317 & $11(0.290)$ & 0.24 & $11(0.222), 20(0.115)$ \\
\hline
\end{tabular}


Table 2. Cont.

\begin{tabular}{ccccccc}
\hline \multirow{2}{*}{ DMU } & \multicolumn{2}{c}{$\mathbf{2 0 1 1}$} & \multicolumn{2}{c}{$\mathbf{2 0 1 2}$} & \multicolumn{2}{c}{$\mathbf{2 0 1 3}$} \\
\cline { 2 - 7 } & Efficiency & RS( $\boldsymbol{\lambda})$ & Efficiency & RS $(\boldsymbol{\lambda})$ & Efficiency & RS $(\boldsymbol{\lambda})$ \\
\hline 11 & 1.000 & $11(1.000)$ & 1.000 & $11(1.000)$ & 1.000 & $11(1.000)$ \\
12 & 0.259 & $11(9.605)$ & 0.23 & $11(9.857)$ & 0.18 & $11(8.392), 20(1.378)$ \\
13 & 0.157 & $11(3.647)$ & 0.15 & $11(3.781)$ & 0.129 & $11(3.217), 20(0.436)$ \\
14 & 0.456 & $11(0.816)$ & 0.458 & $11(0.891)$ & 0.379 & $11(0.647), 20(0.381)$ \\
15 & 0.211 & $11(1.462)$ & 0.216 & $11(1.385)$ & 0.178 & $11(1.011), 20(0.710)$ \\
16 & 0.127 & $11(0.084)$ & 0.133 & $11(0.087)$ & 0.11 & $11(0.061), 20(0.029)$ \\
17 & 0.738 & $11(0.542)$ & 0.636 & $11(0.438)$ & 0.572 & $11(0.368), 20(0.087)$ \\
18 & 0.327 & $11(0.961)$ & 0.307 & $11(0.990)$ & 0.236 & $11(0.700), 20(0.849)$ \\
19 & 0.493 & $11(4.501)$ & 0.461 & $11(4.477)$ & 0.394 & $11(3.967)$ \\
20 & 0.808 & $11(0.275)$ & 0.835 & $11(0.341)$ & 1.000 & $20(1.000)$ \\
\hline
\end{tabular}

DMU 11 was the most carbon efficient company for three consecutive years, indicating that this firm emitted the least carbon and consumed the least energy per unit sale. DMU 20 continued to increase carbon efficiency and finally reached the efficient frontier in 2013. DMU 7 was the least efficient firm, and remained at the lowest efficiency, indicating that it did not make any improvement over the three years.

The result presents the reference set, which is a set of the most efficient units that can be regarded as benchmarks for inefficient units [44]. The numerical value of an inefficient DMU's input variable multiplied by lambda represents the possibility of improvement. Carbon inefficiency implies excessive GHG emissions and energy consumption by a given output (i.e., sales), providing a direction toward how to increase carbon efficiency for each DMU.

Table 3 presents the reduction potential in GHG emissions and energy consumption of all DMUs. For example, the level of carbon efficiency of DMU 1 in 2013 was relatively low at 0.064 . To reach the efficiency level of its benchmark units, DMU 11 and DMU 20, DMU 1 should reduce its inputs as the weighted sum of 0.75 times compared to DMU 11 and 0.619 times compared to DMU 20. The GHG potential of each DMU's emissions and energy consumption reduction were calculated regarding the reference units DMU 11 for 2011 and 2012, and DMU 11 and DMU 20 for 2013. As of 2013, the total carbon reduction potential ranged from about 5.5 million tons to 18.3 million tons depending on the level of efficiency improvement, $30 \%$ to $100 \%$, respectively.

Table 3. Reduction potentials in GHG emissions and energy usage.

\begin{tabular}{|c|c|c|c|c|c|c|}
\hline \multirow[b]{2}{*}{ DMU } & \multicolumn{2}{|c|}{2011} & \multicolumn{2}{|c|}{2012} & \multicolumn{2}{|c|}{2013} \\
\hline & $\begin{array}{c}\text { GHG } \\
\text { Emission } \\
\left(\times 10^{3} \mathrm{tCO}_{2}\right)\end{array}$ & $\begin{array}{c}\begin{array}{c}\text { Energy } \\
\text { Consumption } \\
\left(\times 10^{3} \mathrm{TJ}\right)\end{array} \\
\end{array}$ & $\begin{array}{c}\text { GHG } \\
\text { Emission } \\
\left(\times 10^{3} \mathrm{tCO}_{2}\right)\end{array}$ & $\begin{array}{c}\text { Energy } \\
\text { Consumption } \\
\left(\times 10^{3} \mathrm{TJ}\right)\end{array}$ & $\begin{array}{c}\text { GHG } \\
\text { Emission } \\
\left(\times 10^{3}+\mathrm{CO}_{2}\right)\end{array}$ & $\begin{array}{c}\begin{array}{c}\text { Energy } \\
\text { Consumption } \\
\left(\times 10^{3} \mathrm{TJ}\right)\end{array} \\
\end{array}$ \\
\hline 1 & $2,527,762$ & 36,981 & $2,469,194$ & 38,340 & $2,408,770$ & 37,914 \\
\hline 2 & 379,592 & 4199 & 370,645 & 4696 & 377,619 & 6444 \\
\hline 3 & $1,889,781$ & 20,259 & $1,894,618$ & 21,185 & $1,751,402$ & 22,007 \\
\hline 4 & 81,894 & 964 & 94,893 & 1363 & 133,087 & 2506 \\
\hline 5 & 320,191 & 2422 & 394,778 & 4263 & 375,997 & 5191 \\
\hline 6 & 839,918 & 16,233 & 883,063 & 17,043 & 862,570 & 16,783 \\
\hline 7 & 100,029 & 1003 & 103,534 & 1020 & 96,295 & 970 \\
\hline 8 & 20,763 & 354 & 18,853 & 364 & 16,433 & 328 \\
\hline 9 & 312,429 & 5290 & 327,721 & 5848 & 442,228 & 7771 \\
\hline 10 & 127,199 & 1843 & 128,425 & 1799 & 132,183 & 2252 \\
\hline 11 & 0 & 0 & 0 & 0 & 0 & 0 \\
\hline 12 & $4,441,176$ & 83,390 & $5,020,171$ & 94,974 & $5,778,879$ & 110,977 \\
\hline
\end{tabular}


Table 3. Cont.

\begin{tabular}{|c|c|c|c|c|c|c|}
\hline \multirow[b]{2}{*}{ DMU } & \multicolumn{2}{|c|}{2011} & \multicolumn{2}{|c|}{2012} & \multicolumn{2}{|c|}{2013} \\
\hline & $\begin{array}{c}\text { GHG } \\
\text { Emission } \\
\left(\times 10^{3} \mathrm{tCO}_{2}\right)\end{array}$ & $\begin{array}{c}\text { Energy } \\
\text { Consumption } \\
\left(\times 10^{3} \mathrm{TJ}\right)\end{array}$ & $\begin{array}{c}\text { GHG } \\
\text { Emission } \\
\left(\times 10^{3} \mathrm{tCO}_{2}\right)\end{array}$ & $\begin{array}{c}\text { Energy } \\
\text { Consumption } \\
\left(\times 10^{3} \mathrm{TJ}\right)\end{array}$ & $\begin{array}{c}\text { GHG } \\
\text { Emission } \\
\left(\times 10^{3} \mathrm{tCO}_{2}\right)\end{array}$ & $\begin{array}{c}\text { Energy } \\
\text { Consumption } \\
\left(\times 10^{3} \mathrm{TJ}\right)\end{array}$ \\
\hline 13 & $3,028,540$ & 59,256 & $3,148,667$ & 61,443 & $3,208,230$ & 62,328 \\
\hline 14 & 239,233 & 2956 & 230,318 & 3027 & 207,262 & 3460 \\
\hline 15 & $1,138,267$ & 16,607 & 932,815 & 14,413 & 968,900 & 15,706 \\
\hline 16 & 119,537 & 1745 & 108,678 & 1635 & 91,273 & 1574 \\
\hline 17 & 37,822 & 582 & 45,724 & 721 & 43,839 & 819 \\
\hline 18 & 571,787 & 5996 & 546,830 & 6420 & 592,611 & 8631 \\
\hline 19 & 744,154 & 14,043 & 729,048 & 15,363 & 817,568 & 17,413 \\
\hline 20 & 37,847 & 198 & 252,935 & 193 & 0 & 0 \\
\hline \multicolumn{7}{|c|}{ GHG reduction potential } \\
\hline $30 \%$ & $5,087,376$ & & $5,310,273$ & & $5,491,544$ & \\
\hline $50 \%$ & $8,478,961$ & & $8,850,455$ & & $9,152,573$ & \\
\hline $70 \%$ & $11,870,545$ & & $12,390,637$ & & $12,813,602$ & \\
\hline $100 \%$ & $16,957,921$ & & $17,700,910$ & & $18,305,146$ & \\
\hline
\end{tabular}

\subsection{Changes in Firms' Carbon Efficiency}

Table 2 indicates that firms' carbon efficiency had a tendency to decrease over the three years from 2011. DMU 8 and DMU 20 showed improvements in their carbon efficiency; however, the carbon efficiency of the other DMUs decreased. The carbon efficiency measured by DEA is relative efficiency among DMUs at a particular point in time, so we need to be careful in explaining what might cause such changes in carbon efficiency before and after 2012 [45]. In this section, we examined the possible effect of the TMS policy that came into effect in 2012 on such changes by using an additional analysis to identify a trend of efficiency changes from a time-series aspect. We employed a DEA window analysis that can handle cross-sectional and time-varying data and can therefore measure the dynamic effects of efficiency [46]. By analyzing changes in each DMU's carbon efficiency before and after the TMS in 2012, this study identifies how the TMS policy influenced the efficiency improvements of DMUs.

We conducted DEA window analysis using the following procedures. First, considering $N$ DMUs $(n=1, \ldots, N)$ observed over $T$ periods $(t=1, \ldots, T)$, the sample has $N \times T$ observations. For a window length (or width) of $K$, we evaluated efficiency of $N \times K$ DMUs for each window. In this study, we set $K=2$ as the literature recommended $K=(T+1) / 2$ when time periods for analysis are odd [37]. Second, we analyzed the average efficiency for each window. For $K=2$, the total number of windows become 2 (i.e., $T-K+1$ ). Collectively, the DEA window analysis was carried out based on observations of year $(N=20)$ over periods $(T=3)$ with window length $(K=2)$.

Table 4 presents the results of the DEA window analysis. LDP represents the largest difference between scores across the entire period.

Table 4. Window analysis results and carbon efficiency change.

\begin{tabular}{cccccccc}
\hline DMUs & $\mathbf{2 0 1 1}$ & $\mathbf{2 0 1 2}$ & $\mathbf{2 0 1 3}$ & $\begin{array}{c}\text { Window } \\
\text { Average }\end{array}$ & $\begin{array}{c}\text { Overall } \\
\text { Average }\end{array}$ & $\begin{array}{c}\text { Standard } \\
\text { Deviation }\end{array}$ & LDP \\
\hline \multirow{2}{*}{1} & 0.1125 & 0.0801 & & 0.0963 & 0.0813 & 0.0189 & 0.0483 \\
\hline \multirow{2}{*}{2} & 0.0685 & 0.0642 & 0.0664 & 0.3174 & 0.2769 & 0.0441 & 0.1156 \\
\hline
\end{tabular}


Table 4. Cont.

\begin{tabular}{|c|c|c|c|c|c|c|c|}
\hline DMUs & 2011 & 2012 & 2013 & $\begin{array}{l}\text { Window } \\
\text { Average }\end{array}$ & $\begin{array}{l}\text { Overall } \\
\text { Average }\end{array}$ & $\begin{array}{l}\text { Standard } \\
\text { Deviation }\end{array}$ & LDP \\
\hline 3 & 0.2617 & $\begin{array}{l}0.2418 \\
0.2023\end{array}$ & 0.1810 & $\begin{array}{l}0.2518 \\
0.1917\end{array}$ & 0.2217 & 0.0318 & 0.0807 \\
\hline 4 & 0.7848 & $\begin{array}{l}0.7727 \\
0.6698\end{array}$ & 0.5829 & $\begin{array}{l}0.7788 \\
0.6264\end{array}$ & 0.7026 & 0.0823 & 0.2019 \\
\hline 5 & 0.6357 & $\begin{array}{l}0.4393 \\
0.3707\end{array}$ & 0.3312 & $\begin{array}{l}0.5375 \\
0.3510\end{array}$ & 0.4442 & 0.1171 & 0.3045 \\
\hline 6 & 0.1456 & $\begin{array}{l}0.1444 \\
0.1255\end{array}$ & 0.1232 & $\begin{array}{l}0.1450 \\
0.1244\end{array}$ & 0.1347 & 0.0103 & 0.0224 \\
\hline 7 & 0.0437 & $\begin{array}{c}0.044 \\
0.0359\end{array}$ & 0.0430 & $\begin{array}{l}0.0439 \\
0.0395\end{array}$ & 0.0417 & 0.0033 & 0.0081 \\
\hline 8 & 0.4332 & $\begin{array}{l}0.4719 \\
0.4108\end{array}$ & 0.4849 & $\begin{array}{l}0.4526 \\
0.4479\end{array}$ & 0.4502 & 0.0296 & 0.0741 \\
\hline 9 & 0.0886 & $\begin{array}{l}0.0874 \\
0.0755\end{array}$ & 0.0558 & $\begin{array}{c}0.0880 \\
0.06565\end{array}$ & 0.0768 & 0.0131 & 0.0328 \\
\hline 10 & 0.3044 & $\begin{array}{l}0.3165 \\
0.2703\end{array}$ & 0.2401 & $\begin{array}{l}0.3105 \\
0.2552\end{array}$ & 0.2828 & 0.0299 & 0.0764 \\
\hline 11 & 0.9433 & $\begin{array}{l}1.0000 \\
0.8739\end{array}$ & 1.0000 & $\begin{array}{l}0.9717 \\
0.9370\end{array}$ & 0.9543 & 0.0519 & 0.1261 \\
\hline 12 & 0.2441 & $\begin{array}{l}0.2298 \\
0.1996\end{array}$ & 0.1801 & $\begin{array}{l}0.2370 \\
0.1899\end{array}$ & 0.2134 & 0.0251 & 0.0640 \\
\hline 13 & 0.1483 & $\begin{array}{l}0.1503 \\
0.1308\end{array}$ & 0.1294 & $\begin{array}{l}0.1493 \\
0.1301\end{array}$ & 0.1397 & 0.0096 & 0.0209 \\
\hline 14 & 0.4297 & $\begin{array}{l}0.4584 \\
0.3919\end{array}$ & 0.3792 & $\begin{array}{l}0.4441 \\
0.3856\end{array}$ & 0.4148 & 0.0313 & 0.0792 \\
\hline 15 & 0.1987 & $\begin{array}{l}0.2165 \\
0.1857\end{array}$ & 0.1780 & $\begin{array}{l}0.2076 \\
0.1819\end{array}$ & 0.1947 & 0.0146 & 0.0385 \\
\hline 16 & 0.1196 & $\begin{array}{l}0.1325 \\
0.1132\end{array}$ & 0.1098 & $\begin{array}{l}0.1261 \\
0.1115\end{array}$ & 0.1188 & 0.0087 & 0.0227 \\
\hline 17 & 0.6964 & $\begin{array}{c}0.6362 \\
0.551\end{array}$ & 0.5715 & $\begin{array}{l}0.6663 \\
0.5613\end{array}$ & 0.6138 & 0.0571 & 0.1454 \\
\hline 18 & 0.3084 & $\begin{array}{l}0.3071 \\
0.2589\end{array}$ & 0.2357 & $\begin{array}{l}0.3078 \\
0.2473\end{array}$ & 0.2775 & 0.0313 & 0.0727 \\
\hline 19 & 0.4648 & $\begin{array}{l}0.4609 \\
0.4028\end{array}$ & 0.3942 & $\begin{array}{l}0.4629 \\
0.3985\end{array}$ & 0.4307 & 0.0323 & 0.0706 \\
\hline 20 & 0.7622 & $\begin{array}{l}0.8352 \\
0.6612\end{array}$ & 1.0000 & $\begin{array}{l}0.7987 \\
0.8306\end{array}$ & 0.8145 & 0.1236 & 0.3388 \\
\hline
\end{tabular}

DMU 20 was the only company that showed an improvement in carbon efficiency before and after 2012. While DMU 11 steadily maintained the highest carbon efficiency for the periods (average carbon efficiency $=0.9543$ ), DMU 7 ranked the lowest (average carbon efficiency $=0.0417$ ). We classified the higher efficiency group and lower efficiency group by considering the average efficiency level of all DMUs (0.3443). The result indicates a significant gap in carbon efficiency between the two groups (the average of the higher efficiency group $=0.6653$; the average of the lower efficiency group $=0.2134$ ) 
This study did not find evidence that the carbon efficiency of Korean petrochemical companies increased before and after TMS introduction in 2012. We provide possible interpretations. First, among the 20 DMUs, two of the highest carbon-efficient firms (i.e., DMU 11 and DMU 20) were dominant; therefore, the other companies' carbon efficiency appeared to be relatively low. For instance, DMU20 has developed a clean development mechanism (CDM) projects overseas and was thus able to reserve a huge amount of certified emission reductions (CER). Using carbon offsets with such CERs, this company was able to maintain the highest level of carbon efficiency without compromising sales decreases. DMU 11 also stayed on the efficient frontier for three years of analysis. It produces construction materials and chemical products whose production processes are more carbon-efficient than other products, even in the same petrochemical industry. In short, different levels of carbon efficiency might be attributed to the characteristics of products and production processes. Second, the TMS imposes certain levels of GHG emissions reduction targets in terms of absolute percentage or relative efficiency, onto companies subject to this regulation. DEA might find it difficult to detect any changes in carbon efficiency if most of the TMS-participating companies achieve their reduction targets and thus fully comply with the regulation at the same time. The South Korean government instated another carbon policy, namely the ETS, in 2015 to provide companies with more flexibility and autonomy based on market mechanisms in setting reduction targets and achieving them. This study could be applied to the ETS to examine firms' carbon efficiency before and after the introduction of the ETS.

\subsection{Stakeholder Pressure, Carbon Management Practices, and Carbon Efficiency}

The results of the DEA show differences in carbon efficiency of the Korean petrochemical companies subject to the TMS policy. In this section, we explore possible antecedents that might influence firms' carbon efficiency by focusing on two factors: stakeholder pressure as an external factor and carbon management practices as an internal factor. As explained in the methodology section, stakeholder pressure and carbon management practices were measured by perceptual measurement using a survey.

Table 5 presents descriptive statistics and correlation analysis among variables. In general, carbon efficiency does not have significant correlations with stakeholder pressure and carbon management practices. Low-carbon product development, however, is significantly correlated with carbon efficiency at a 5 percent cutoff level. It has a positive and significant relationship with pressure from financial investors.

The $t$-test was used to examine the effects of stakeholder pressure and corporate carbon management practices on carbon efficiency. Based on the median value of each question item (four items for stakeholders pressure and four items for carbon management practices), we classified the sample into two groups of "higher than or equal to the median" and "lower than the median". Then we tested the statistical significance of the differences in average carbon efficiency between the two groups. The results of the $t$-test are summarized in Table 6 . 
Table 5. Results of descriptive statistics and correlation analysis.

\begin{tabular}{|c|c|c|c|c|c|c|c|c|c|c|}
\hline Variables & Mean & S.D. & 1 & 2 & 3 & 4 & 5 & 6 & 7 & 8 \\
\hline 1. Carbon efficiency & 0.36 & 0.27 & - & & & & & & & \\
\hline 2. Regulatory agencies & 5.37 & 1.01 & -0.19 & - & & & & & & \\
\hline 3. Customers & 4.88 & 0.88 & 0.23 & 0.37 & - & & & & & \\
\hline 4. Media & 4.79 & 0.87 & 0.32 & 0.17 & $0.57^{* *}$ & - & & & & \\
\hline 5. Financial investors & 4.6 & 0.88 & 0.37 & $0.43^{+}$ & 0.26 & $0.44 *$ & - & & & \\
\hline 6. Low-carbon product development & 5.2 & 0.89 & $0.52 *$ & 0.18 & 0.33 & 0.36 & $0.64^{* *}$ & - & & \\
\hline 7. Process efficiency improvement & 5.85 & 1.04 & -0.12 & -0.07 & 0.35 & 0.37 & 0.05 & 0.09 & - & \\
\hline 8. Energy source substitute & 4.65 & 1.73 & -0.05 & -9.07 & 0.02 & 0.11 & 0.15 & 0.28 & 0.12 & - \\
\hline 9. Organizational engagement & 4.8 & 1.36 & -0.23 & -0.13 & 0.04 & 0.23 & 0.11 & 0.12 & $0.68^{* *}$ & $0.46^{*}$ \\
\hline
\end{tabular}

Note: Carbon efficiency is the value of the three-year average (2011 through 2013). ${ }^{+} p<0.1{ }^{*} p<0.05 ;{ }^{* *} p<0.01$. 
Table 6. Results of the $t$-test of the effects of stakeholder pressure and carbon management practices on carbon efficiency.

\begin{tabular}{|c|c|c|c|}
\hline \multirow{2}{*}{ Variables } & \multicolumn{2}{|c|}{ Carbon Efficiency (Mean) } & \multirow[t]{2}{*}{$t$-Value } \\
\hline & Upper & Lower & \\
\hline \multicolumn{4}{|l|}{ Stakeholder pressure } \\
\hline \multirow[t]{2}{*}{ Regulatory agencies } & 0.305 & 0.409 & 2.14 \\
\hline & $(\mathrm{n}=27)$ & $(n=33)$ & \\
\hline \multirow[t]{2}{*}{ Customers } & 0.429 & 0.317 & 2.47 \\
\hline & $(\mathrm{n}=24)$ & $(n=36)$ & \\
\hline \multirow[t]{2}{*}{ Media } & 0.425 & 0.299 & $3.30^{+}$ \\
\hline & $(n=30)$ & $(\mathrm{n}=30)$ & \\
\hline \multirow[t]{2}{*}{ Financial investors } & 0.414 & 0.298 & $2.74^{+}$ \\
\hline & $(n=33)$ & $(\mathrm{n}=27)$ & \\
\hline \multicolumn{4}{|l|}{ Carbon management practice } \\
\hline \multirow[t]{2}{*}{ Low-carbon product development } & 0.493 & 0.275 & $10.53 *$ \\
\hline & $(n=24)$ & $(n=36)$ & \\
\hline \multirow[t]{2}{*}{ Process efficiency improvement } & 0.354 & 0.375 & 0.08 \\
\hline & $(\mathrm{n}=36)$ & $(\mathrm{n}=24)$ & \\
\hline \multirow[t]{2}{*}{ Energy source substitute } & 0.394 & 0.345 & 0.42 \\
\hline & $(n=21)$ & $(n=39)$ & \\
\hline \multirow[t]{2}{*}{ Organizational engagement } & 0.285 & 0.404 & 2.61 \\
\hline & $(\mathrm{n}=21)$ & $(n=39)$ & \\
\hline
\end{tabular}

First, media and financial investors are shown to have a positive relationship with carbon efficiency at a 0.1 cutoff level. Companies that perceive higher pressure for addressing climate change issues from media and financial investors are likely to put more effort into increasing carbon efficiency. Media plays a critical role in scrutinizing GHG heavy emitters by exposing them to the public. The petrochemical companies might endeavor to reduce GHG emissions when they are more exposed to the media, which leads to higher carbon efficiency. The financial sector has paid increasing attention to climate change. For instance, the Carbon Disclosure Project (CDP), a consortium of over 300 institutional investors with $\$ 41$ trillion in assets, has asked the world's 500 largest firms to disclose their GHG emissions, risk, opportunities, and management strategies every year. Korean firms started participating in the CDP in 2006. Large-sized and heavy polluting firms in the petrochemical industry tend to actively participate in this disclosure project, which leads to have opportunity to increase carbon efficiency. This is consistent with the legitimacy theory, indicating that companies whose social legitimacy is threatened have incentive to increase environmental performance and disclosure [47].

Second, the low-carbon product development practice has a significant and positive effect on carbon efficiency at a 0.05 cutoff level. Companies that focus on the development of less carbon-intensive or carbon-free production are able to increase carbon efficiency. In the petrochemical industry, changes in products affect overall production processes of supply chain partners as well as the firms' own processes, by enabling them to conduct better housekeeping and energy recovery [30]. This result implies that investments in energy-efficient product/technology developments for reducing products' carbon footprints might enhance carbon efficiency of petrochemical companies overall. Effects of other carbon management practices on carbon efficiency, however, were not found in this study. 


\section{Conclusions}

This study analyzed carbon efficiency of the Korean petrochemical companies subject to the Target Management System, a Korean government climate change policy, from a dynamic change perspective. The current research also examined the effects of stakeholder pressure and firms' carbon management practices on carbon efficiency. The results of this study can be summarized as follows. First, petrochemical companies showed very different levels of carbon efficiency. Two of the most efficient companies were distinctive while average carbon efficiency was at 0.34 and the company with the lowest efficiency remained at only 0.05 . The results imply that the potential for GHG emission reduction in the Korean petrochemical industry would amount to 12 million tons of carbon dioxide equivalent $\left(\mathrm{CO}_{2 \mathrm{e}}\right)$ when companies in this industry were assumed to improve their carbon efficiency up to $70 \%$ of the most efficient benchmark companies. Second, the gap in carbon efficiency of companies is wide. As a limited number of carbon efficient companies became more dominant, the carbon efficiency of the majority of the petrochemical companies continued to weaken. As a result, the effect of the TMS carbon policy on carbon efficiency was not observed. Third, this study provided evidence that some stakeholder pressure and carbon management practices had a positive relationship with carbon efficiency. Media and financial investors might have an influence on carbon efficiency. Firms' effort toward low-carbon product/technology development also improves carbon efficiency.

As one of the early studies on carbon efficiency of firms, this research provides some practical and policy implications. First, policy-makers need to consider firms' competitive stance when they are willing to introduce carbon policies such as the TMS and the emission trading scheme (ETS). Firms are likely to be reluctant or even resistant to newly adopted carbon policies. Carbon policies should be designed to be favorable to climate-proactive companies to facilitate firms to collaborate with governments in achieving national carbon reduction goals. For instance, various types of incentives need to be provided to carbon-efficient companies. Second, policy-makers need to implement carbon policies in conjunction with the media and financial sector, which are known to influence firms to take a proactive stance towards climate change issues. The government could collaborate with the carbon disclosure project (the CDP), a voluntary consortium of over 300 institutional climate change movement in the financial sector with $\$ 41$ trillion in assets has annually requested large firms to disclose their carbon emissions, related risks and opportunities, and strategies, to encourage firms to adopt and implement carbon management practices and thus improve their carbon efficiency. Third, policy-makers should have a long-term perspective in implementing carbon policies. They might find it difficult to observe how carbon policies influence firms' competitiveness in a short period. Less carbon-efficient firms might need time to narrow the gap to more carbon-efficient benchmarks. Carbon policies need to be phased and tailored to higher and lower carbon-efficient groups. They also need to monitor changes in carbon efficiency over time. Fourth, firms should have a forward-looking stance toward climate change and its related policies. By improving carbon efficiency, they need to manage carbon-related risks as well as seek business opportunities engendered by climate change. Fifth, firms also need to keep censoring which and how external stakeholders demand that they address climate change. They should recognize the positive effect of stakeholder pressure, particularly media and the financial sector, in improving their carbon efficiency. Sixth, firms should strengthen investment in low-carbon product and technology development. Such effort enhances their carbon efficiency, indicating that they could reduce GHG emissions while increasing revenues.

By clarifying some limitations of this study, we suggest directions for future research. First, to analyze carbon efficiency using DEA, this study focused on the petrochemical industry. The approach used in this study needs to be applied to other carbon-intensive sectors such as steel, power, and pulp and paper industries. Second, to the authors' knowledge, this paper is the first study to examine the effect of carbon policies regarding firms' carbon efficiency. This study focuses on the TMS in Korea which are considered a preliminary carbon policy before instating the Korea ETS in 2015. Future research needs to re-test changes in firms' carbon efficiency before and after the Korea ETS. Third, significant research is required to understand the effects of firms' carbon efficiency and 
management practices in different contexts. For instance, China is planning to launch a nationwide ETS. The research framework of this study could be applied to such different country contexts to deliberately examine differences and similarities in the effect of carbon policies among emerging economies. Third, the long-term effect of such carbon policies on firms' carbon efficiency needs to be explored. Besides, future research also needs to consider other variables that might influence carbon efficiency. Leanness of operations, absorptive capacity, and organizational learning might be some exemplary antecedents of high carbon efficiency.

Author Contributions: S.-H.L. designed the study, collected data, and conducted statistical data analysis. S.-Y.L. wrote the manuscript with several practical implications and S.-H.L. read and approved the final manuscript.

Funding: This research received no external funding.

Conflicts of Interest: The authors declare no conflict of interest.

\section{Appendix A}

Table A1. Questionnaire items used for this study.

\begin{tabular}{|c|}
\hline Stakeholder Pressure \\
\hline $\begin{array}{l}\text { How has the following stakeholder's pressure influenced your firm to address climate change for the last three years? } \\
(1=\text { very low to } 4=\text { moderate to } 7 \text { = very high) }\end{array}$ \\
\hline $\begin{array}{l}\text { 1. Regulatory agencies } \\
\text { 2. Customers } \\
\text { 3. Media } \\
\text { 4. Financial Investors }\end{array}$ \\
\hline Carbon management practices \\
\hline $\begin{array}{l}\text { To which extent do you agree or disagree for each of the following statement }(1=\text { not at all, } 4=\text { moderately, } \\
7 \text { = very extensive)? } \\
\text { Over the past two years, your firm }\end{array}$ \\
\hline $\begin{array}{l}\text { 1. Low-carbon product development-has continued to develop energy-efficient or less carbon-intensive products } \\
\text { 2. Process efficiency improvements-has continued to undertake projects to increase energy-efficiency in your } \\
\text { production processes } \\
\text { 3. Energy source substitutions-has substituted existing energy sources with cleaner fuels } \\
\text { 4. Organizational engagement-has engaged the entire organization by utilizing internal emission trading schemes }\end{array}$ \\
\hline
\end{tabular}

\section{References}

1. Intergovernmental Panel on Climate Change (IPCC). Climate Change 2007: Impacts, Adaptation and Vulnerability; Cambridge University Press: Cambridge, UK, 2007.

2. Intergovernmental Panel on Climate Change (IPCC). Managing the Risks of Extreme Events and Disasters to Advance Climate Change Adaptation; Cambridge University Press: Cambridge, UK, 2012.

3. Stern, N.; Treasury, H.M. The Economics of Climate Change: The STERN Review; Cambridge University Press: Cambridge, UK, 2007.

4. Howard-Grenville, J.; Buckle, S.J.; Hoskins, B.J.; George, G. Climate change and management: From the editors. Acad. Manag. J. 2014, 57, 615-623. [CrossRef]

5. Lash, J.; Wellington, F. Competitive advantage on a warming planet. Harv. Bus. Rev. 2007, 85, 94-102. [PubMed]

6. Kolk, A.; Pinkse, J. Business responses to climate change: Identifying emergent strategies. Calif. Manag. Rev. 2005, 47, 6-20. [CrossRef]

7. International Energy Agency (IEA). Energy Technology Perspectives 2016: Towards Sustainable Urban Energy System; IEA: Paris, France, 2016.

8. Greenhouse Gas Inventory and Research Center. National Greenhouse Gas Inventory Report of Korea; Greenhouse Gas Inventory and Research Center: Seoul, Korea, 2016. (In Korean)

9. Ahn, Y.H.; Lee, S.Y. Climate-entrepreneurship in response to climate change: Lessons from the Korean emission trading scheme (ETS). Int. J. Clim. Chang. Strateg. Manag. 2018. [CrossRef] 
10. Delmas, M.; Toffel, M.W. Stakeholders and environmental management practices: An institutional framework. Bus. Strateg. Environ. 2004, 13, 209-222. [CrossRef]

11. Lee, S.Y.; Klassen, R.D. Firms' response to climate change: The interplay of business uncertainty and organizational capabilities. Bus. Strateg. Environ. 2016, 25, 577-592. [CrossRef]

12. Delmas, M.; Toffel, M.W. Organizational responses to environmental demands: Opening the Black Box. Strateg. Manag. J. 2008, 29, 1027-1055. [CrossRef]

13. Banerjee, S.B. Corporate environmental strategies and actions. Manag. Decis. 2001, 39, 36-44. [CrossRef]

14. Lee, J.Y.; Kim, Y.K.; Lee, C.K.; Rhee, Y.H. A Study on the calculation of GHG emission for domestic railroad transport based on IPCC guideline. J. Korean Soc. Railw. 2012, 15, 408-412. (In Korean) [CrossRef]

15. Lee, S.Y.; Kang, M.O.; Chae, Y.R.; Ko, S.J. Greenhouse Gas Emissions Trading Scheme DESIGN considering Target Management System; Korea Environment Institute: Seoul, Korea, 2012. (In Korean)

16. Oggioni, G.; Riccardi, R.; Toninelli, R. Eco-efficiency of the world cement industry: A data envelopment analysis. Energy Policy 2011, 39, 2842-2854. [CrossRef]

17. Kang, I.K.; Sim, G.S.; Kim, J.Y. Eco-efficiency analysis of target management enterprises for greenhouse gases and energy using DEA. Korean Corp. Manag. Assoc. 2014, 21, 1-25. (In Korean)

18. Mardania, A.; Zavadskasb, E.K.; Streimikienec, D.; Jusoha, A.; Khoshnoudia, M. A comprehensive review of data envelopment analysis (DEA) approach in energy efficiency. Renew. Sustain. Energy Rev. 2017, 70, 1298-1322. [CrossRef]

19. Zadeh, A.H.; Afshari, H.; Salehi, S.; Fathi, M.; Zadeh, A.H.; Borna, M.A.; Timar, M. Eco-efficiency measurement by implementing DEA models with weight restrictions. In Proceedings of the 6th International Conference on Soft Computing Models in Industrial and Environmental Application (SOCO 2011), Salamanca, Spain, 6-8 April 2011; pp. 309-318.

20. Kuosmanen, T.; Kortelainen, M. Measuring eco-efficiency of production with data envelopment analysis. J. Ind. Ecol. 2005, 9, 59-72. [CrossRef]

21. World Business Council for Sustainable Development (WBCSD). Eco-Efficiency: Learning Module; WBCSD: Geneva, Switzerland, 1992. Available online: http:/ / www.wbcsd.org (accessed on 7 July 2017).

22. Cho, Y.R.; Lee, H.Y.; Park, Y.T. Analyzing eco-efficiency of eco-friendly services using DEA: A case of carsharing services. Proc. Korean Oper. Res. Manag. Sci. Soc. 2010, 862-869. (In Korean)

23. Park, J.H.; Ok, H.M.; Cha, K.H.; Hur, T. Tackling challenges in measuring and communicating eco-efficiency. In Proceedings of the 2006 IEEE International Symposium on Electronics and the Environment, Francisco, CA, USA, 8-11 May 2006.

24. Figge, F.; Hahn, T. Sustainable value added measuring corporate contributions to sustainability beyond eco-efficiency. Ecol. Econ. 2004, 48, 173-187. [CrossRef]

25. Schmidheiny, S.; Zorraquin, F.J.L. Financing Change, the Financial Community, Eco-efficiency and Sustainable Development; MIT Press: Cambridge, MA, USA, 1996.

26. Mahlberg, B.; Luptacik, M.; Sahoo, B.K. Examining the drivers of total factor productivity change with an illustrative example of 14 EU countries. Ecol. Econ. 2011, 72, 60-69. [CrossRef]

27. Zhang, B.; Fan, J.; Bi, Z.; Yuan, Z.; Ge, J. Eco-efficiency analysis of industrial system in China: A data envelopment analysis approach. Ecol. Econ. 2008, 68, 306-316. [CrossRef]

28. Korhonen, P.J.; Luptacik, M. Eco-efficiency analysis of power plants: An extension of data envelopment analysis. Eur. J. Oper. Res. 2004, 154, 437-446. [CrossRef]

29. Sprengel, D.C.; Busch, T. Stakeholder engagement and environmental strategy-The case of climate change. Bus. Strateg. Environ. 2011, 20, 351-364. [CrossRef]

30. Lee, S.Y.; Kim, Y.H. Antecedents and consequences of firms' climate change management practices: Stakeholder and synergistic approach. Sustainability 2015, 7, 14521-14536. [CrossRef]

31. Lee, S.Y. Corporate carbon strategies in responding to climate change. Bus. Strateg. Environ. 2012, $21,33-48$. [CrossRef]

32. McKinsey \& Company. How companies think about climate change: A McKinsey Global Survey. Mckinsey Quarterly, 1 December 2007; pp. 1-10.

33. Lee, S.Y. Existing and anticipating technology strategies for reducing greenhouse gas emissions in Korea's petrochemical and steel industries. J. Clean. Prod. 2013, 40, 83-92. [CrossRef]

34. Pinkse, J.; Kolk, A. Challenges and trade-offs in corporate innovation for climate change. Bus. Strateg. Environ. 2010, 19, 261-272. [CrossRef] 
35. Jeswani, H.K.; Wehrmeyer, W.; Mulugetta, Y. How warm is the corporate response to climate change? Evidence from Pakistan and the UK. Bus. Strateg. Environ. 2008, 17, 46-60. [CrossRef]

36. Charnes, A.; Cooper, W.W.; Rhodes, E. Measuring the efficiency of decision making units. Eur. J. Oper. Res. 1978, 2, 429-444. [CrossRef]

37. Cooper, W.W.; Seiford, L.M.; Tone, K. Data Envelopment Analysis: A Comprehensive Text with Models, Applications, Reference and DEA-Solver Software; Kluwer Academic Publishers: Dordrecht, The Netherlands, 2000.

38. Goedkoop, M.J.; van Halen, C.J.G.; te Riele, H.R.M.; Rommens, P.J.M. Product Service Systems, Ecological and Economic Basis; Ministry of Housing, Spatial Planning and the Environment Communications Directorate: The Hague, The Netherlands, 1999.

39. Meijkamp, R. Changing consumer behaviour through eco-efficient services: An empirical study of car sharing in the Netherlands. Bus. Strateg. Environ. 1998, 7, 234-244. [CrossRef]

40. Schumock, G.T.; Butler, M.G.; Meek, P.D.; Vermeulen, L.C.; Arondekar, B.V.; Bauman, J.L. Evidence of the economic benefit of clinical pharmacy services: 1996-2000. Pharmacotherapy 2003, 23, 113-132. [CrossRef] [PubMed]

41. Fitzsimmons, J.A.; Fitzsimmons, M.J. Service Management for Competitive Advantag; McGraw-Hill College: New York, NY, USA, 1994.

42. Boussofiane, A.; Dyson, R.G.; Thanassoulis, E. Applied data envelopment analysis. Eur. J. Oper. Res. 1991, 1, 1-15. [CrossRef]

43. Banker, R.D.; Charnes, A.; Cooper, W.W. Some models for estimating technical and scale inefficiencies in data envelopment analysis. Manag. Sci. 1984, 30, 1078-1092. [CrossRef]

44. Jahanshahloo, G.R.; Shirzadi, A.; Mirdehghan, S.M. Finding the reference set of a decision making unit. Asia-Pac. J. Oper. Res. 2008, 25, 563-573. [CrossRef]

45. Thompson, R.G.; Lee, E.; Thrall, R.M. DEA/AR-efficiency of U.S. independent oil/gas producers over time. Comput. Oper. Res. 1992, 19, 377-391. [CrossRef]

46. Wang, K.; Yu, S.; Zhang, W. China's regional energy and environmental efficiency: A DEA window analysis based dynamic evaluation. Math. Comput. Model. 2013, 58, 1117-1127. [CrossRef]

47. Gray, R.; Kouhy, R.; Lavers, S. Corporate social and environmental reporting: A review of the literature and a longitudinal study of UK disclosure. Acc. Audit. Account. J. 1995, 8, 47-77. [CrossRef]

(C) 2018 by the authors. Licensee MDPI, Basel, Switzerland. This article is an open access article distributed under the terms and conditions of the Creative Commons Attribution (CC BY) license (http:/ / creativecommons.org/licenses/by/4.0/). 